\title{
ASPIRININE ASTMA - ASTMOS KLINIKINIS VARIANTAS
}

\author{
SANDRA RAGAIŠIENE், DOC. DR. BRIGITA ŠITKAUSKIENE்
}

KMU PULMONOLOGIJOS IR IMUNOLOGIJOS KLINIKA

\begin{abstract}
Reikšminiai žodžiai: astma, aspirininė, NVNU, paracetamolis, COX-1.
Santrauka. Aspirininė astma yra atskiras retesnis klinikinis astmos variantas, kuriam būdinga tai, kad paūmejjimą išprovokuoja aspirino ar kitų nesteroidinių vaistų nuo uždegimo (NVNU) vartojimas. Literatūros duomenimis, sergamumas aspirinine astma siekia 0,3-0,6 proc., 0 iš astmos ligonių aspirinui jautrūs nuo 3 proc. iki 22 proc. Šiam astmos variantui būdingas padidejęs jautrumas vaistams, kurie slopina COX-1 fermentą. Dèl šios priežasties keičiasi arachidono rūgšties metabolizmas ir gaminasi daugiau leukotrienų. Aspirininei astmai būdinga triada: bronchų obstrukcijos sindromas, padidejjęs jautrumas NVNU, rinosinusitas ar nosies polipozė. Jos paūmeejimą dažniausiai lydi rinitas, akių perštėjimas ir karščio jutimas bei raudonis veide. Ligos eiga paprastai būna sunki ir užsitęsusi. Net ir nevartojant aspirino ar NVNU, astmos simptomai dažniausiai savaime neišnyksta, šiai ligai būdingas progresavimas.
\end{abstract}

Astma - viena labiausiai paplitusių ligų ir, nepaisant akivaizdaus medicinos progreso, sergamumas šia liga dideja. Astmos simptomus gali provokuoti alergenai, fizinis krūvis, virusinẻ kvėpavimo takų infekcija, vaistai (dažniau acetilsalicilo rūgštis bei kiti NVNU) ir pan. Aspirininè astma yra viena retesnių astmos klinikinių išraiškų. Jai būdinga specifiški simptomai, intensyvus eozinofilinis nosies ir bronchų gleivinès uždegimas ir kartu padidejęs cistenil-leukotrienų (Cys-LT) kiekis. Anksčiau buvo manoma, kad aspirininė astma yra klinikinè „alergijos“ aspirinui išraiška, tačiau dabar jau aišku, kad daugumai pacientų simptomus sukelia skirtingos struktūros NVNU, dèl to galima teigti, kad šio sindromo patogenezę lemia ne alerginiai ir ne imuniniai mechanizmai. Literatūroje šis sindromas vadinamas ir kitaip: Francis triada, Samter triada bei aspirininè triada.

Pirmasis padidejusio jautrumo aspirinui klinikinis atvejis literatūroje aprašytas 1902 metais, o 1968 Samter ir Beers aprašè triadą, kurią sudarè astma, jautrumas aspirinui ir nosies polipozè. 1998 metais ịrodyta, jog sergant aspirinine astma nosies gleivinès ir bronchų reakciją i aspiriną lemia $\mathrm{LTC}_{4}$ ir histaminas. 2001 metais nustatyta, kad aspirininès astmos simptomus provokuoja tie NVNU, kurie selektyviai slopina COX-1.

\section{PAPLITIMAS}

Aspirininès astmos dažnumas populiacijoje yra 0,30,6 proc. Priklausomai nuo to, kaip aspirininè astma diagnozuojama (tik pagal anamnezę ar atlikus provo- kacinị mėgini su aspirinu, pasirinktus jautrumo reakcijos kriterijus, tiriamos populiacijos pobūdì), jautrumas aspirinui nustatomas nuo 3 proc. iki 22 proc. astma sergančių pacientų, dažniau vidutinio sunkumo ir sunkia astma bei nosies polipoze. Dauguma šių pacientų neturi atopijos požymių.

A. Szczeklik su bendradarbiais teigia, kad atlikus provokacinius méginius ir spirometrinius matavimus, aspirininè astma nustatoma 8-20 proc. astmos ligonių, kitų tyrèjų duomenimis, jei diagnozė grindžiama tik anamneze, ligos dažnumas tesiekia apytikriai 5 proc. Vis dèlto, ịtarus aspirininę astmą ir atlikus provokacinius mėginius, apie 35 proc. pacientuc mėginiai būna neigiami.

Tyrimai rodo, kad aspirininès astmos simptomai anksčiau pasireiškia moterims, be to, liga būna sunkesnès eigos ir greičiau progresuoja. Toks dèsningumas aiškinamas lytinių hormonų poveikiu imuniniam atsakui ir atsikūrimo mechanizmams.

\section{PATOGENEZE்}

Aspirinas ar kiti NVNU slopina COX-1 fermentą kvėpavimo takuose, todèl arachidono rūgšties metabolizmas toliau vyksta neịprastu būdu - dalyvaujant 5 lipoksigenezei, dèl to sumažeja prostaglandinų sintezè. Vienas iš COX-1 mediatorių, reguliuojantis normalų organizmo funkcionavimą, yra prostaglandinas $\mathrm{E}_{2}\left(\mathrm{PGE}_{2}\right)$. Tyrimais įrodyta, kad vaistai, kurie slopina $\mathrm{COX}$ ir tuo pačiu mažina $\mathrm{PGE}_{2}$ kiekị, aktyvina kitą fermentų kelią, dèl to daugiau gaminasi uždegimo mediatorių leukotrienų. Būtent leukotrienai ir yra pagrindiniai aspirininès astmos paūmèjimo mediatoriai. 


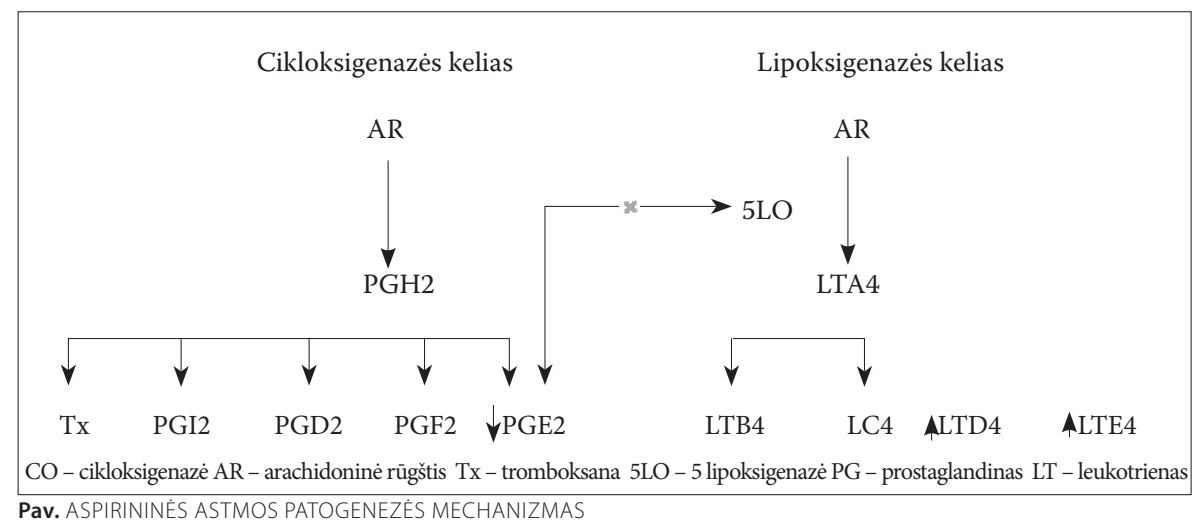

Nosies polipų imunohistocheminiais tyrimais nustatytas padidejęs eozinofilų ir degranuliuotų putliụjų ląstelių kiekis. Aspirinui sukèlus bronchų konstrikciją, padidèja triptazès bei eozinofiluc katijoninio baltymo kiekis serume. Padidejęs eozinofilų bei cys-LT ir IL-5 kiekis buvo nustatytas ir bronchų bei alveolių išplovose. Cys-LT, kurio sintezè priklauso nuo LTC $_{4}$ sintazès, taip pat padaugèja nosies sekrete bei šlapime.

\section{SIMPTOMAI}

Dažniausiai aspirininès astmos paūmèjimą lydi rinitas ir karščio jutimas bei raudonis veide. Kartais šie simptomai atsiranda dar prieš paūmèjimą. Aspirininès astmos eiga gali būti labai sunki ir pavojinga. Klinikiniai simptomai skiriasi ir nuo astmos, kuria sergama nuo vaikystès, ir nuo alerginès astmos. Simptomai paprastai pirmą kartą pasireiškia apie 30-uosius gyvenimo metus, vargina nuolatinè vandeningo pobūdžio sloga, nosies užgulimas ir čiaudulys. Dẻl augančių nosies polipu dviem trečdaliams pacientų sutrinka uoslè (dažnai tenka kartoti polipektomijas). Nustatyta, kad astmos simptomai pasireiškia vidutiniškai po dvejų metų nuo rinito pradžios, o jautrumas aspirinui ir kitiems NVNU po ketverių metų. Pavartojus aspirino ar kito NVNU, reakcija dažniausiai prasideda lètai, po 30 minučių ar net trijų valandų. Nors ši liga vadinama aspirinine astma, tyrimais įrodyta, kad pacientai gali būti jautrūs visiems NVNU, kurie slopina COX fermentą, išskyrus paracetamoli (acetaminofeną). Tyrimais ịrodyta, kad iš dalies paracetamolio skausmą slopinantis poveikis pasireiškia per naujai nustatytą COX-3 izofermentą, tuo tarpu aspirininès astmos patogenezei svarbu COX-1. C. Jenkins su bendradarbiais nustatè, kad iš aspirinine astma sergančių pacientų paracetamoliui jautrūs tik 7 proc. Pagal šiuos duomenis tik mažiau nei 2 proc. astma sergančiuc pacientų bus jautrūs ir aspirinui, ir paracetamoliui.

Svarbu žinoti, kad jautrumas aspirinui išlieka ilgai, o astmos eiga dažniausiai tampa sunkesnè, nepaisant to, kad aspirino ir kitų NVNU nevartojama.

\section{GYDYMAS}

Pacientams, kuriems nustatytas padidejęs jautrumas aspirinui, galima atlikti desensibilizaciją aspirinu. To- kiu atveju kryžmiškai sumažejja jautrumas ir kitiems NVNU. Desensibilizacija palengvina astmos eigą, sulètèja polipu augimas, pacientai rečiau serga sinusitu. Tyrimais įrodyta, kad po desensibilizacijos kasdien vartojant dideles aspirino dozes sumažẻja gleivinès (daugiausia nosies) uždegimo požymiai.

Desensibilizacija tik pašalina pagrindinị astmos paūmèjimus provokuojantị veiksnị, tačiau pačios ligos neišgydo, todèl ilgalaikiam gydymui pagrindiniai tebėra kontroliuojamieji uždegimą slopinantys vaistai gliukokortikosteroidai ir leukotrienų receptorių antagonistai.

Pagrindinis medikamentinio astmos gydymo tikslas - pasiekti ir išlaikyti astmos kontrolę. Siekiant šio tikslo, mūsų šalyje vadovaujamasi Globalios astmos gydymo ir profilaktikos strategijos (GINA) komiteto bei mūsų šalyje specialistų periodiškai atnaujinamomis rekomendacijomis.

Lentelè. ANALGETIKỤ VARTOJIMO REKOMENDACIJOS ASTMA SERGANTIEMS PACIENTAMS (PAGAL C. JENKINS ET AL. "SYSTEMATIC REVIEW OF PREVALENCE OF ASPIRIN INDUCED ASTHMA AND ITS IMPLICATIONS FOR CLINICAL PRACTICE"BMJ, 2004)

\begin{tabular}{ll}
\hline Pacientų grupė & Rekomendacijos \\
\hline Visi pacientai, kuriems diagno- & Pacientai turètų vengti visų \\
zuota aspirininė astma; visi pa- & produktų, kurių sudėtyje yra as- \\
cientai, kuriems kada nors yra & pirino ar NVNU; galima vartoti \\
buvęs astmos paūmèjimas pavar- & paracetamolio, jei nèra kontra- \\
tojus aspirino ar kito NVNU & indikacijų. \\
(pvz., ibuprofeno, diklofenako), \\
visi pacientai, kuriems nustatyti \\
aspirininės astmos rizikos veiks- \\
niai (sunkūs astmos simptomai, \\
nosies polipozé, dilgèlinè ar \\
nuolatinis rinitas)
\end{tabular}

Jaunesni nei 40 metų pacien- Aspirininè astma gali pasireikštai arba nevartoję aspirino ar ti vèliau, taigi pacientus būtina NVNU informuoti apie galimą riziką vartojant aspirino ar kito NVNU Rekomenduojama vartoti paracetamolio, jei nèra kontraindikacijų. Jei būtinas NVNU, pirmą dozę pacientas turètų suvartoti prižiūrimas gydytojo.

Visi kiti astma sergantys Galima vartoti bet kurị analgetipacientai ką. Jei vartojant pasirinktą vaista atsiranda kokių nors kvėpavimo sutrikimu, rekomenduojamavaisto vartojimą nutraukti ir kreiptis i gydytoją. 


\section{PROFILAKTIKA}

Kitaip nei alerginès reakcijos, padidèjęs jautrumas aspirinui atsiranda nepriklausomai nuo to, ar pacientas buvo kada vartojęs aspirino, kitą NVNU ar ne. Aspirinas šiuo atveju yra tik paūmèjimą provokuojantis veiksnys, bet ne ligos priežastis, todèl svarbu žinoti, kad ir nevartojant aspirino astmos simptomai savaime neišnyks. Nors nevartojant NVNU galima išvengti paūmejjimų, šiai ligai būdingas progresavimas. Nustatyta, kad maisto produktų, kuriuose yra salicilatų, vartojimas ligos eigos nekeičia.

C. Jenkins su bendradarbiais, išanalizavę aspirininès astmos dažnumą bei kryžmines reakcijas su kitais NVNU, pateike analgetikų vartojimo rekomendacijas (lentelè).

Daug jautrumo aspirinui atvejų lieka nediagnozuota, kadangi aspirino provokacinis mėginys nèra iprastinis tyrimas ir neatliekamas astma sergantiems pacientams, jei jie nenurodo patyrę aspirino sukeltą reakciją.

Gliukokortikosteroidu ar ilgo veikimo inhaliuojamųjų beta 2 adrenoreceptorių agonistų kartu su gliukokortikosteroidais vartojimas gali paslèpti šią ligą. Tai ir yra pagrindinès priežastys, dažniausiai nulemiančios sunkesnę ligos eigą ar jos padarinius.

\section{ASPIRIN-INDUCED ASTHMA - A DISTINCT SYNDROME}

\author{
SANDRA RAGAIŠIENE், BRIGITA ŠITKAUSKIENE \\ DEPARTMENT OF PULMONOLOGY AND IMMUNOLOGY \\ KAUNAS UNIVERSITY OF MEDICINE
}

Key words: asthma, aspirin-induced, NSAIDs, paracetamol, COX-1. Summary. Aspirin-induced asthma (AIA) is a distinct clinical asthma type and it is characterized by asthma attacks following the ingestion of aspirin and other non-steroidal anti-inflammatory drug (NSAID). The prevalence of AIA has been reported to be about 0.3-0.6 \%. in population and the prevalence in patients with asthma have varied between $3-22 \%$. The common characteristic of this syndrome is the sensitivity to the medications that inhibit the COX-1 enzyme. This pathological pathway is associated with alterations in arachidonate metabolism and results in cysteinyl-leukotriene overproduction. Bronchial obstruction, sensitivity to NSAIDs and rhinosinusitis or nasal polyps are the main symptoms of AIA. Nasoocular symptoms and facial flushing often accompany the asthma attack. The course of the disease is more severe and persistent. Avoidance of aspirin and NSAIDs does not prevent the progression and does not result in resolution of asthma. AIA may be life threatening and may have severe consequences for patients. Thus, it is important to present an overview of principal clinical information about AIA.

\section{LITERATŪRA}

1. Nizankowska-Mogilnicka E, Bochenek G, Mastalerz L, Swierczynska M, Picado $C$, et al. EAACI/GA2LEN guideline: aspirin provocation tests fo diagnosis of aspirin hypersensitivity. Allergy 2007;62(10):1111-1118.

2. Mastalerz L, Sanuok M, Gawlewicz A, Gielicz A, Faber J, et al. Different eicosanoid profile of the hypersensitivity reactions triggered by aspirin and celecoxib in a patient with sinusitis, asthma, and urticaria. J Allergy Clin Immunol 2006:118(4):957-958.

3. Szczeklik A, Sanak M. The broken balance in aspirin hypersensitivity. Eur J Pharmacol 2006;8;533(1-3):145-155.

4. Szczeklik A, Musial J, Undas A, Sanak M. Aspirin resistance. J Thromb Haemost 2005:3(8):1655-1662.

5. Sakalauskas R, Bagdonas A, Blažienè A, Bojarskas J, Danila E, et al. Lietuvos vaiku ir suaugusiuju astmos diagnostikos ir gydymo sutarimas. Kaunas, UAB “Vitae Litera” 2007; 1-56.

6. Global Strategy for Asthma Management and PreventionGlobal Initiative for Asthma (GINA) 2007, update. Available from: http://www ginasthma.org.

7. Szczeklik A, Sanak M, Nizankowska-Mogilnicka E, Kielbasa B. Aspirin intolerance and the cyclooxygenase-leukotriene pathways.

Curr Opin Pulm Med 2004:10(1):51-56.

8. Jenkins C, Costello J, Hodge L. Systematic review of prevalence of aspirin induced asthma and its implications for clinical practice. BMJ 2004;328-434

9. Jenkins C, Costello, J, Hodge L. Asthma and simple over-the-counter analgesics: An evidence-based review of the prevalence of aspirin-induced asthma and its implications for clinical practice. BMJ 2003.

10. Vally $\mathrm{H}$, Taylor ML, Thompson PJ. The prevalence of aspirin intolerant asthma (AIA) in Australian asthmatic patients. Thorax 2002:57:569-574.

11. Chandrasekharan NV, Dai H, Roos KL, Evanson NK, Tomsik J, et al. COX-3, a cyclooxygenase-1 variant inhibited by acetaminophen and other analgesic/ antipyretic drugs: cloning, structure, and expression. Proc Nat Acad Sci USA 2002;99:13926-31.

12. Stevenson DD, Sanchez-Borges M, Szczeklik A. Classification of allergic and pseudoallergic reactions to drugs that inhibit cyclooxgenase. Ann Allergy Asthma Immunology 2001;87:177-180.

13. Dahlen B, Szczeklik A, Murray JJ. Celecoxib in patients with asthma and aspirin intolerance. The Celecoxib in Aspirin-Intolerant Asthma Study Group. N Engl J Med. 2001;344(2):142.

14. Levy $S$, Volans $G$. The use of analgesics in patients with asthma. Drug Safety 2001;24:829-41.

15. Stevenson DD, Simon RA. Lack of cross-reactivity between rofecoxib and aspirin in aspirin-sensitive patients with asthma. J Allergy Clin Immunol 2001;108(1):47-51

16. Szczeklik A, Nizankowska E, Duplaga M. Natural history of aspirin-induced asthma. Eur Respir J 2000;16:432-6.

17. Nizankowska E, Bestynska-Krypel A, Cmiel A, Szczeklik A. Oral and bronchial provocation tests with aspirin for diagnosis of aspirin-induced asthma. Eur Respir J 2000;15:863-9. 